\title{
TWENTY-SIX SECONDS ON TETONIA-3
}

Time for a change.

BY WENDY NIKEL

$\mathrm{I}$ took twenty-six seconds for the freshly terraformed landscape of Tetonia- 3 to be painted over with chemical dust and radiation from the reactor explosion.

Twenty-six seconds to lose everything.

I know what the report will say before Marcus holds it up to the glass.

For six months, while they've huddled inside the habitat, arguing, debating and making desperate calculations, I've made do outside, on a farm where nothing grows but bitter moss and bloodred berries. Where the Earth-born livestock bear peculiar, strangelimbed offspring that wander without fear of natural predators. A five-legged colt that sings. Piglets with roaming third eyes. Earless calves that spend their days in the moss fields, staring at the blinding double suns. Even the eggs I eat glow luminous in the dark and smell vaguely of burning sulfur.

But I know what must be done.

Abort mission.

This plot of land - this farm in this valley we'd claimed as our own - has been poisoned, and to start over elsewhere on Tetonia-3 would involve too much time, too much money, too much risk. The winds, the clouds, the spin of the planet itself have flung the contaminants too wide already.

"And me?" I sign.

"I won't leave you," Marcus mouths. The implication's there: the others would. They gave me up for dead long ago.

Six months ago, I stood at the hatch, pleading to be let in, but the automated quarantine locks held tight, and those with the ability to override it were millions of miles away. When the initial wave passed, and I still stood there, wracked with nausea and terror-stricken but alive, he was still there, too, his hand pressed against the window. Even now, his face in the convex glass seems distorted in pain.

His stubbornness is how I ended up on this mission: even those holding humanity's future in their hands couldn't refuse his choice of crewmates. It's how I ended up in the programme to begin with: he wouldn't let me listen to my self-doubts. In the end, I reasoned I'd be OK, as long as I was with him; surely even fate itself would have to conform to his will.

But the stars above Tetonia-3 don't align as

blocks the light in the window, and I raise a hand in greeting.

The horse beneath me startles, rears.

My balance falters. My arms flail. I tumble.

The hostile ground jolts me, cracks and rattles my bones against its stone. Red runs down my face, stings my eyes and stains my hands. My body collapses, unmoving, and I lie still. Perfectly still.

Over the sound of frantic horsesong, I hear him pounding on the window as if from far away. As if from the other end of the galaxy.

I lie there for what seems like hours, until the pounding ceases and silence affirms his defeat. Until the horses grow weary of trying to nudge me back to life and wander off to nibble on bitter moss. Until the wind picks up and biting chemical rain falls from purple-black clouds, forming puddles around my cold body.

It's a shame to be remembered as a victim, not of the travails of space or the harshness of an inhospitable planet - things that would have made Marcus's chest swell with pride while

they did on Earth. Not even for him.

The others set the launch date, but still Marcus rebuffs all urging.

"The lock won't open till the air clears," I sign, "and you only have six more months of food. You need to go."

"I can't."

"Why not?"

"It's my fault you're here."

It takes me two days to devise a plan and three more to work up the courage I'd normally rely on Marcus to bolster. I cannot let the gloom of his guilt grow here, mutating into something grotesque and overfilling the space in my memories where happier times ought to be.

I cannot watch him starve.

On the morning of the launch, I gather some berries, saddle the horse, and gallop to the habitat. The quintaped colt skips along
ONATURE.COM Follow Futures:

@ @NatureFutures

$f$ go.nature.com/mtoodm behind its mother, trilling a song whose strangeness no one else will ever hear.

Marcus's shadow delivering my eulogy - but of a simple accident that could've happened on Earth. But I lie there, still, listening to the colt's distant melody until the rocket blast tears the song from my mind and dries the red berry juice I'd smeared across my face.

The colt nudges me again, humming of bitter moss and luminous eggs and the lonely shadow of the abandoned habitat.

Only then do I open my eyes. Only then do I allow myself a full breath. Together with the calves, I track the bright tail of the rocket into the clouds, and I count the seconds until it's gone. Until he's gone.

It takes twenty-six seconds for the rocket to disappear, to burst free from the poisoned skies and certain death of this tainted, oncehopeful world. Twenty-six seconds for me to pull myself up and brush off the dust and grime of my deceit.

Twenty-six seconds to say goodbye.

Wendy Nikel is a speculative-fiction author with a degree in elementary education, a fondness for road trips and a terrible habit of forgetting where she's left her cup of tea. For more info, visit wendynikel.com. 